\title{
EFFECT OF CHEMICAL CORROSION ON THE PERMEABILITY OF ROCKS BELOW LANDFILLS AND ON THE MIGRATION OF POLLUTANTS
}

\author{
JIN, X. ${ }^{1,2,3}-$ FENG, Y., ${ }^{1,2,3 *}$ \\ ${ }^{1}$ School of Civil Engineering, Chongqing University, Chongqing 400045, China \\ ${ }^{2}$ Key Laboratory of New Technology for Construction of Cities in Mountain Area (Chongqing \\ University), Ministry of Education, Chongqing 400045, China \\ ${ }^{3}$ National Joint Engineering Research Center of Geohazards Prevention in the Reservoir Area \\ (Chongqing), Chongqing 400045, China \\ (phone: +86-189-8383-0834) \\ *Corresponding author \\ e-mail: 727178971@qq.com; phone: + 86-83-9420-2720 \\ (Received 23 $3^{\text {rd }}$ May 2019; accepted $2^{\text {nd }}$ Sep 2019)
}

\begin{abstract}
Penetration of the landfill leachate during a tunnel excavation process has a certain impact on the properties of surrounding rocks, including their permeability. The present study was envisaged to analyze such changes by performing a comparative test on the rock specimens with or without being soaked in the landfill leachate. Furthermore, the groundwater flow and solute transport model were established. Tunnel drainage was conceptualized as a pumping well in the confined formation and the weighting factor for hydraulic conductivity coefficient was taken into consideration for specific regions in the model. Subsequently, the water level and the pollutant concentration distribution in these regions were analyzed. The results showed that the simulated groundwater levels on the south and north sides of the tunnel were higher than the original level. Fluctuation in the groundwater level caused by the tunnel drainage was significantly greater due to pumping well PW-1. Because of the soaking of the surrounding rocks in the landfill leachate, the hydraulic conductivity coefficients of these regions increased, which aggravated the downward penetration of the pollutants in the regions between the two tunnels.
\end{abstract}

Keywords: groundwater flow simulation, solute transport simulation, surrounding rocks, hydraulic conductivity coefficient, tunnel excavation

\section{Introduction}

Most municipal waste is disposed in the landfills in China (Zhan et al., 2014). Among these landfills, approximately $40 \%$ are devoid of a bottom liner system and leachate collection system (Du et al., 2009). Many scholars have studied the migration of the landfill leachate by simulation or experimental methods. In one such experiment a solute transport model was established with MT3D software, which simulated the migration process of $\mathrm{Cr} 6+$ leakage in the landfills and addressed the effects of different pollution control measures (Zhou et al., 2014). Han used the Visual MODFLOW software to study the longest distance travelled during the leakage of chloride ions from the landfill in the vertical direction (Han et al., 2014). A DRASTIC model and an MT3D model were further adopted to construct a vulnerability map of the groundwater of the Kinmen landfill (Liu et al., 2011). A three-dimensional solute transport model was established to study the changes in concentrations that found an increase of the sulfate concentrations due to the leaching of sulfate-rich waters from a landfill (Molinero and Samper, 2006) 
Lin and Lee (2009) proposed that the process of constructing a tunnel caused huge disturbances in the surrounding rock, including its hydraulic conductivity coefficient and the distribution of the stress field. Currently, numerous analytical and semianalytical models have been developed to predict the discharge rate per unit length of a tunnel. Tunnel discharge was estimated by simulating the rock as a statistically homogeneous stochastic continuum in two dimensions (Ando et al., 2003). The hydraulic conductivity coefficient and the vertical anisotropy of the studied area, including the tunnel disturbance zone, were incorporated into a simplified expression according to the empirical formula proposed by Ersoy (2013). However, the spatial distribution of the hydraulic conductivity is complex and was difficult to fully characterize (Jiang et al., 2010). Very few studies have focused on the effects on a tunnel below the landfill or on the erosion of the geological media by landfill leachate, which affects the hydraulic conductivity coefficient.

Penetration of the landfill leachate during the tunnel excavation process has a certain impact on the properties of the surrounding rocks, including the permeability of the surrounding rocks. In order to precisely capture the change in permeability of the surrounding rocks under excavation, a simulation is usually needed. Rock specimens obtained from tunnel excavation were processed into standard specimens, which were subsequently soaked in the landfill leachate. Finally, a comparative test was performed on the permeability of rock specimens among the soaked and notsoaked in the landfill leachate. The changes in the permeability of the surrounding rocks soaked in the prepared landfill leachate were characterized. Then, GMS software was used to establish the groundwater flow and solute transport model. Changes in hydraulic conductivity coefficients in the characteristic regions of the model were considered and the groundwater level and pollutant concentration distribution in these regions were analyzed.

\section{Materials and methods}

\section{Working principles}

Rock permeability test was divided into the in-situ test and the laboratory test. Insitu test was performed on site that accurately determined the permeability of the rock and soil mass. However, the in-situ test is time and money-consuming. Laboratory test is easily operable, controllable and reliable, and requires less investment in terms of money or labor resources. There are mainly two methods to test the soil permeability in laboratory, viz. the transient test and the static test.

In the static test, a certain level of penetration pressure is imposed on the two ends of the test specimen. The volume of the fluid penetrating into the rock specimen within a certain period of time is recorded. Then the permeability under this working condition is calculated according to the Darcy's law (Zimmerman et al., 2000; Brace et al., 1968). Static test is easier and more stable than the transient test and requires less time. Therefore, static test was performed in this study. Equations 1 and 2 represent the working principle of the static test, where $\mathrm{q}$ is the flow rate $\left(\mathrm{m}^{3} / \mathrm{s}\right) ; k$ is the permeability $\left(\mathrm{m}^{2}\right) ; A$ is the cross-sectional area of the specimen $\left(\mathrm{m}^{2}\right) ; \mathrm{d} h$ is the pressure head $(\mathrm{m}) ; L$ is the length of the penetration path $(\mathrm{m}) ; \gamma_{f}$ is the fluid density, which is $1000 \mathrm{~kg} / \mathrm{m}^{3}$ for water; $\mu$ is the coefficient of dynamic viscosity of fluid (Pastoules et al., 1982). 


$$
\begin{gathered}
q=-k \frac{\gamma_{f}}{\mu} \cdot \frac{d h}{d x} \cdot A \\
k=\frac{\mu L V}{A \Delta P \Delta t}
\end{gathered}
$$

\section{Test preparations}

The purpose of the landfill leachate concentration test was to determine the pollutant concentration in the leachate that was used to immerse the rock specimens as well as the original landfill leachate concentration. Figure 1 shows the picture of the sampling points at the No. 1 landfill BH-1. Samples were collected once per month from each of the landfills BH-1, BH-2 and BH-3. The GPS coordinates of BH-1, BH-2 and BH-3 were $(30.644927,104.359351),(30.648471,104.362012)$ and $(30.654969,104.363600)$, respectively. The total number of sampling was 12 , and the overall sampling duration was 1 year. The total nitrogen (TN) of the samples was determined by semi-micro Kjeldahl method. The oxidizing agent potassium permanganate $\left(\mathrm{KMnO}_{4}\right)$ was used for measuring chemical oxygen demand (COD). Ammonia nitrogen, chloride and sulfate ions were tested by titration. Subsequently, the pollutant concentrations were measured and processed statistically. Table 1 shows the statistics of the field test results of landfill leachate for the concentrations of $\mathrm{Cl}^{-}, \mathrm{SO}_{4}{ }^{2-}, \mathrm{COD}, \mathrm{TN}, \mathrm{NH}^{4+}-\mathrm{N}$ and $\mathrm{Ph}$ at $\mathrm{BH}-1, \mathrm{BH}-2$ and $\mathrm{BH}-3$, where $\mathrm{Nu}$ is the number of samples collected; $\mathrm{Av}$ is the mean and $\mathrm{Va}$ is the standard deviation of concentration. The unit of concentrations was $m g / L$.

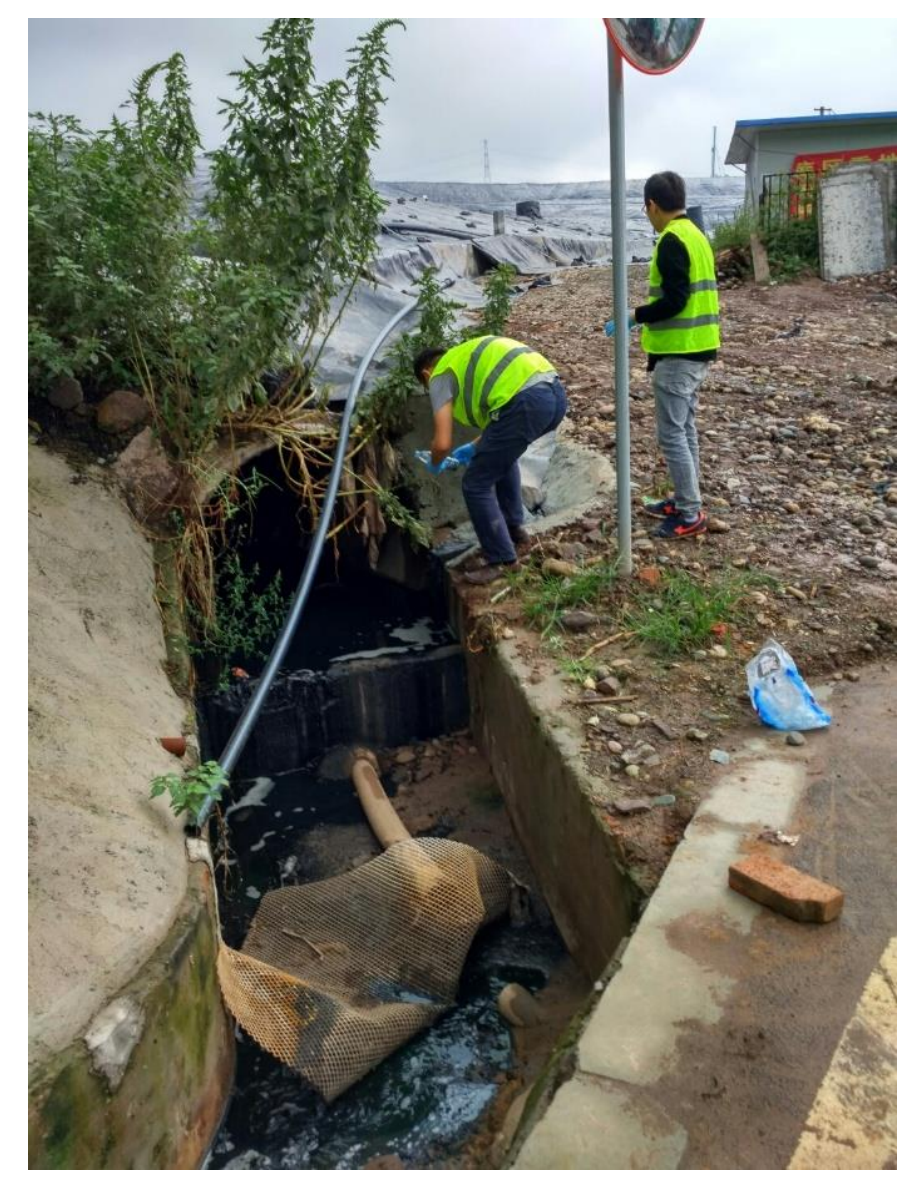

Figure 1. Picture of sampling points at BH-1 
Table 1. Field test results of the landfill leachate (Feng et al., 2019)

\begin{tabular}{|c|c|c|c|c|c|c|c|c|c|c|c|c|c|}
\hline & & \multicolumn{2}{|c|}{$\mathrm{Cl}^{-}$} & \multicolumn{2}{|c|}{$\mathrm{SO}_{4}{ }^{2-}$} & \multicolumn{2}{|c|}{ COD } & \multicolumn{2}{|c|}{ TN } & \multicolumn{2}{|c|}{$\mathrm{NH}_{4}{ }^{+}-\mathrm{N}$} & \multicolumn{2}{|c|}{$\mathbf{P h}$} \\
\hline & $\mathrm{Nu}$ & $A v$ & $V a$ & $A v$ & $V a$ & $A v$ & $V a$ & $A v$ & $V a$ & $A v$ & $V a$ & $A v$ & $V a$ \\
\hline BH-1 & 12 & 3905 & 15877 & 5075 & 11145 & 3786 & 194919 & 1462 & 9604 & 839 & 8476 & 7.59 & 0.012 \\
\hline BH-2 & 12 & 3756 & 20649 & 5136 & 15129 & 3646 & 210261 & 1096 & 10479 & 756 & 5590 & 7.49 & 0.017 \\
\hline BH-3 & 12 & 4102 & 26358 & 4963 & 36289 & 4523 & 79645 & 1236 & 10491 & 563 & 4397 & 7.88 & 0.036 \\
\hline
\end{tabular}

During tunnel excavation, the penetration of landfill leachate causes a certain impact on the surrounding rocks, and the influence on permeability of the surrounding rocks needs to be given a major consideration. In order to determine the changes in the permeability of the surrounding rocks after tunnel excavation, it is important to conduct the experiment by soaking the excavated and processed rock specimens in the landfill leachate. The measured concentration of landfill leachate used was used to prepare the experimental leachate. The mean of pollutant concentration at the sampling points of $\mathrm{BH}$ 1, BH-2 and BH-3 were taken and the leachate samples were prepared by mixing together the different ions in an appropriate proportion. Total nitrogen was defined as the sum of all inorganic and organic nitrogen, including the inorganic $\mathrm{NO}^{3-,} \mathrm{NO}^{2-}$ and $\mathrm{NH}_{4}^{+}$and organic proteins, amino acids and amines. However, the preparation of nitrogencontaining leachate was difficult, and the resulting solution exhibited a low stability. Therefore, nitrogen-containing leachate was not prepared. The prepared landfill leachate was mainly composed of $\mathrm{COD}, \mathrm{SO}_{4}{ }^{2-}, \mathrm{Cl}^{-}, \mathrm{OH}^{-}$and $\mathrm{NH}_{4}{ }^{+}$, and the volume of the prepared solution was $2000 \mathrm{~mL}$ with $\mathrm{Ph}$ value of 8 . Concentrations of each pollutant in the leachate are shown in Table 2, and the soaking time was 60 days (Fig. 2).

Table 2. Concentrations of different pollutants in the prepared leachate

\begin{tabular}{c|c|c|c|c|c}
\hline Pollutant & COD & $\mathbf{S O}_{4}{ }^{2-}$ & $\mathbf{C l}^{-}$ & $\mathbf{N H}_{4}{ }^{+}$ & Ph \\
\hline Concentration $(\mathrm{mg} / \mathrm{L})$ & $4000 * *$ & $5000^{* *}$ & $4000^{* *}$ & $719^{* *}$ & $8^{* *}$ \\
\hline
\end{tabular}

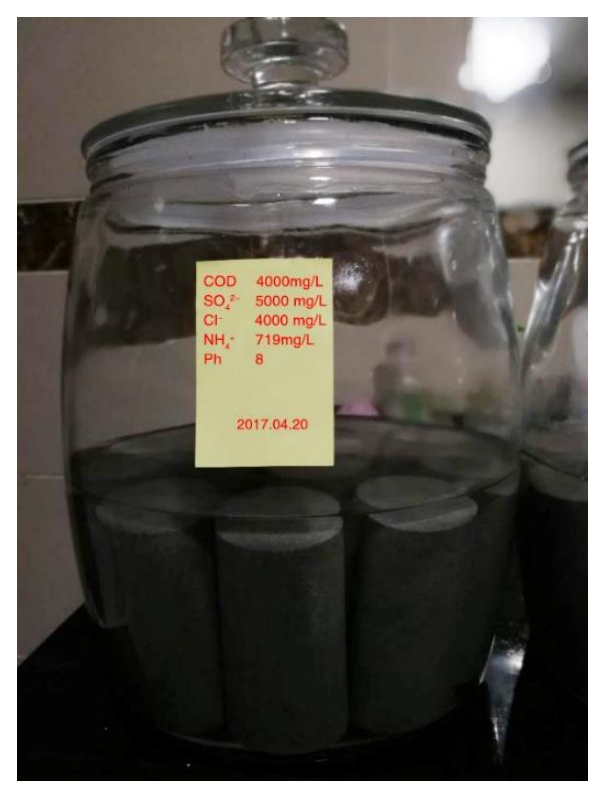

Figure 2. Rock samples after soaking 
The rock specimens were taken out from the leachate and all specimens, with or without soaking, were numbered. Before the permeability test, all the specimens were first soaked in water. The specimens were subjected to vacuum pumping in a pressure vessel for $4 \mathrm{~h}$, followed by dehumidification for another $4 \mathrm{~h}$. Then the specimens were placed into distilled water for $16 \mathrm{~h}$, so that the pores of the rock specimens were filled with water. Moreover, by soaking in water, the external leachate would not stay inside the rock specimens because the pores of the rock specimens were not completely filled with water, thus, impairing accuracy of the test. The permeability test was undertaken by using the TRIAXIAL CELL V 4.0 system, as shown in Figure 3. This system was composed of automatic confining pressure, axial pressure and interstitial fluid pressure servos. The system was suitable for temperature-hydraulic pressure-mechanic-chemistry multi-field coupling test for the geological materials such as rocks.

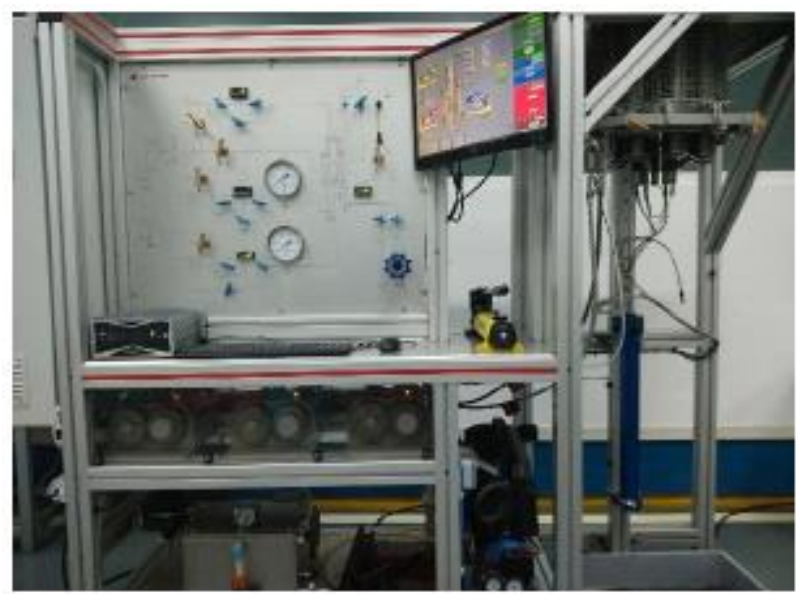

Figure 3. Picture of TRIAXIAL CELL V 4.0

\section{Analysis of test results}

The penetration pressure was set to $2 \mathrm{MPa}$ in the test and the confining pressure test was $4 \mathrm{MPa}$ and $10 \mathrm{M}$. In the meantime, two control groups were set up in order to analyze the influence of the landfill leachate on the permeability of the rock, viz. a group of test specimen not soaked in the leachate and a group of test specimen soaked in the leachate. The test results are displayed in Figures 4 and 5. Two types of curves are shown in the figure, the axial strain-deviatoric stress curve and axial-strainpermeability curve.

It can be seen that the rock permeability was closely related to the confining pressure. Under the penetration pressure of $2 \mathrm{MPa}$, the rock permeability decreased as with an increase in the confining pressure. Under a higher confining pressure, the micropores and microcracks inside the rock specimens were compressed or closed, leading to a reduction in the size of seepage radius and channels. As a result the permeability of the specimens decreased. For specimens with or without soaking, under the penetration pressure of $2 \mathrm{MPa}$, the maximum permeability occurred when the axial strain was 0.8101 , before which the deviatoric stress decreased suddenly. When the confining pressure was $10 \mathrm{MPa}$ and the penetration pressure was $2 \mathrm{MPa}$, a maximum permeability occurred where the axial strain was 0.9954 and 1.2788 , before which the deviatoric stress decreased dramatically. The maximum permeability of the rock 
specimens occurred after the peak strength, that is, after the fracture of specimens. When a macroscopic fracture plane was formed inside the specimen, this plane would become the preferential seepage channel, leading to a sudden increase in permeability. Mean values were taken of the difference in permeability in all specimens with or without being soaked. It was found that the permeability of the specimens soaked in leachate increased by $21 \%$ on average.

\section{Numerical simulation}

\section{Numerical simulation}

Feng et al. (2019) found that if no pollution sources or acid precipitation were identified in the study area, the peak concentration of sulfate ions in water samples collected from tunnels was 438 times that of the background concentration in January 2017. This indicated that the high concentration of sulfate ions in the tunnel was attributed to No. 1 landfill. Han et al. (2016) surveyed 32 scientific research papers on the pollution environment of landfills, and found that sulfate ions leaking from landfills not only pollute the groundwater but also corrode concrete. Chloride ions are relatively stable in the migration process. However, the migration distance is generally short and the sulfate ions will cause severe corrosion of the concrete in the tunnel. So sulfate ions were taken as the object of simulation in the model. Jamrah et al. (2008) proposed that the simulation results without considering the hydrochemical behaviors were very helpful for groundwater governance. Therefore, the hydrochemical behaviors were not considered in the model.

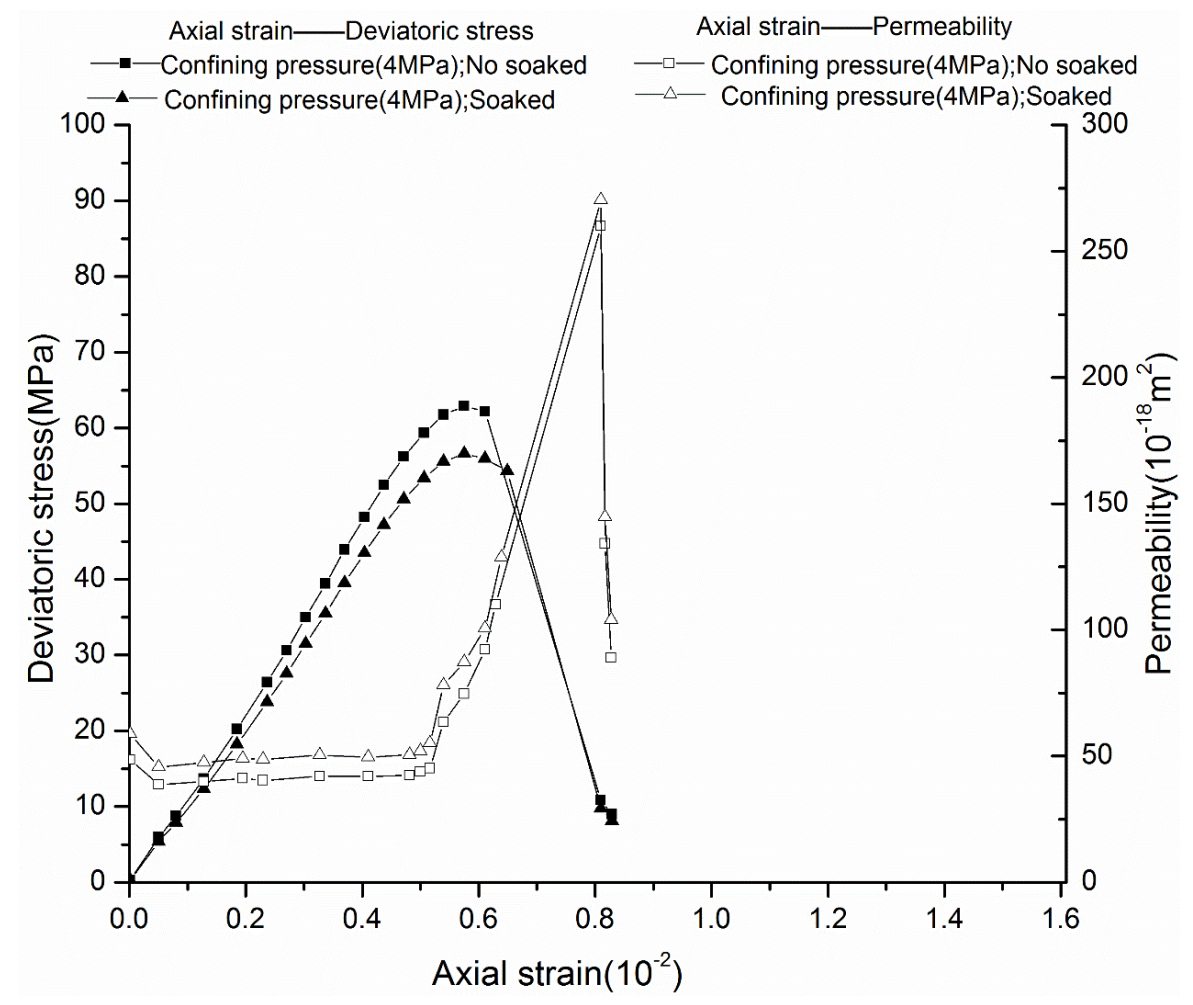

Figure 4. Comparison of the axial strain-deviatoric stress curves and axial-strain-permeability curves in rock specimens soaked or not soaked under the confining pressure of 4 MPa and penetration pressure of $2 \mathrm{MPa}$ 


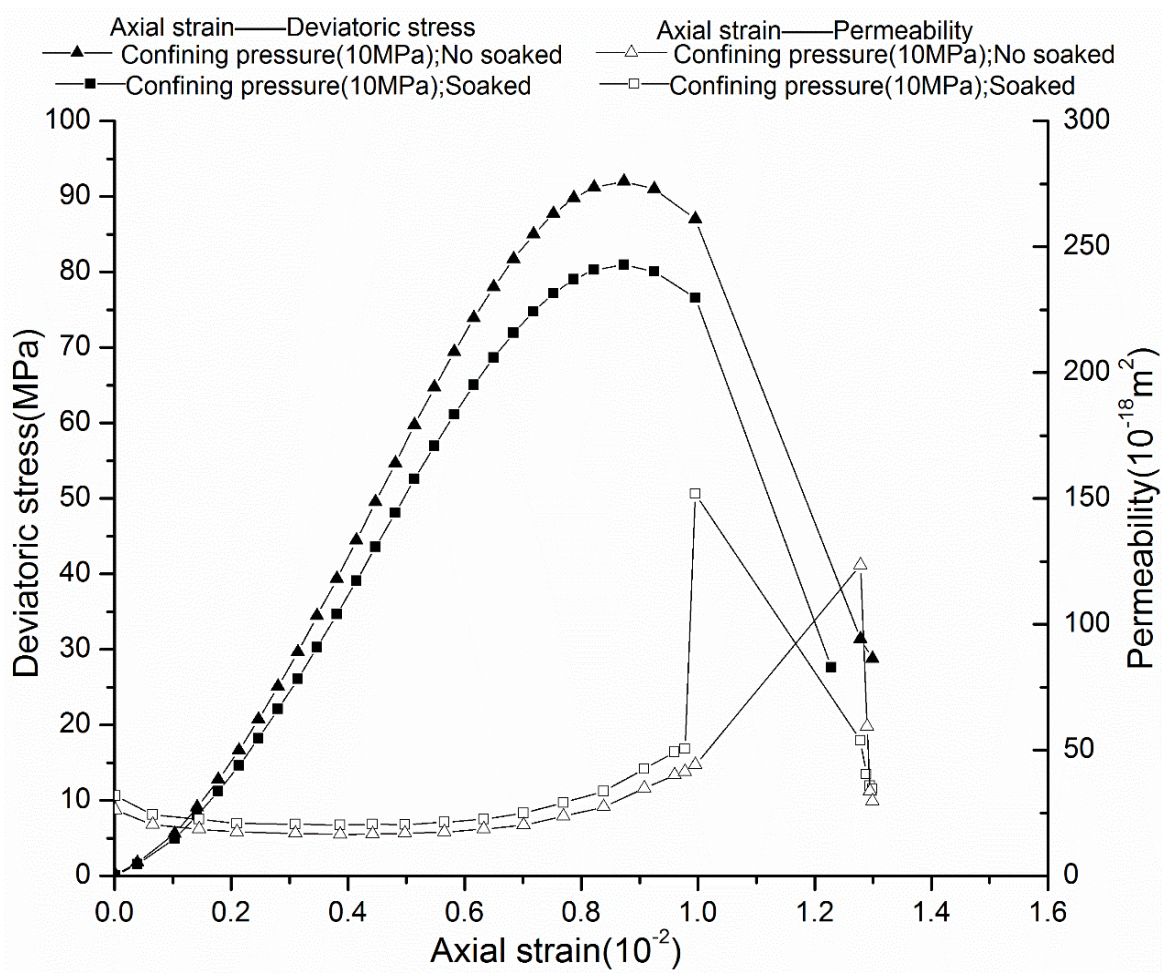

Figure 5. Comparison of the axial strain-deviatoric stress curves and axial-strain-permeability curves in rock specimens soaked or not soaked under the confining pressure of $10 \mathrm{MPa}$ and penetration pressure of $2 \mathrm{MPa}$

The solute transport model (MT3D model) and groundwater flow model (MODFLOW model) in the study were established to simulate the solute transport and the groundwater flow, respectively (McDonald and Harbaugh, 1988; Zheng and Wang, 1999). Both the solute transport model and groundwater flow model were of the transient type. The time duration under simulation was from January 2015 to December 2030 , for a total of stress periods. Configuration of the stress period was consistent with the changes in groundwater recharge, wherein, each month represented one stress period. Multiplier and time step were respectively set to 1.1 and 5 . The boundary conditions, stress period and original conditions in MT3D model were consistent with those in MODFLOW model.

\section{Original water level and boundary conditions}

Feng et al. (2019) established a groundwater model in the study area, the boundary 4 in southwest and the boundary 2 in northeast were both conceptualized as the fixed head boundaries according to the measurements of the monitoring wells along the boundary 4 and boundary 2. Boundary 2 is set along the Shi fan Mountain and the head varied from $669.6 \mathrm{~m}$ to $672.0 \mathrm{~m}$. The head on boundary 4 varied from $666.1 \mathrm{~m}$ to $667.3 \mathrm{~m}$. Due to the presence of the impervious rocks, boundary 3 was set to the zero-flow boundary. Boundary 1 was set along a highway with roadbed, so it was also set as the zero-flow boundary. There were 4 intersections between the boundary 4 and the original water level, indicating that the head on the boundary 4 is reduced from ends to the middle. The boundary view is shown in Figure 6. The original water head is shown in Figure 6 
and the groundwater generally flows from northeast to southwest. In addition, the values of the original head and the elevations of the layers were input in the MODFLOW and MT3D model and then interpolated to get a value for each cell of the models.

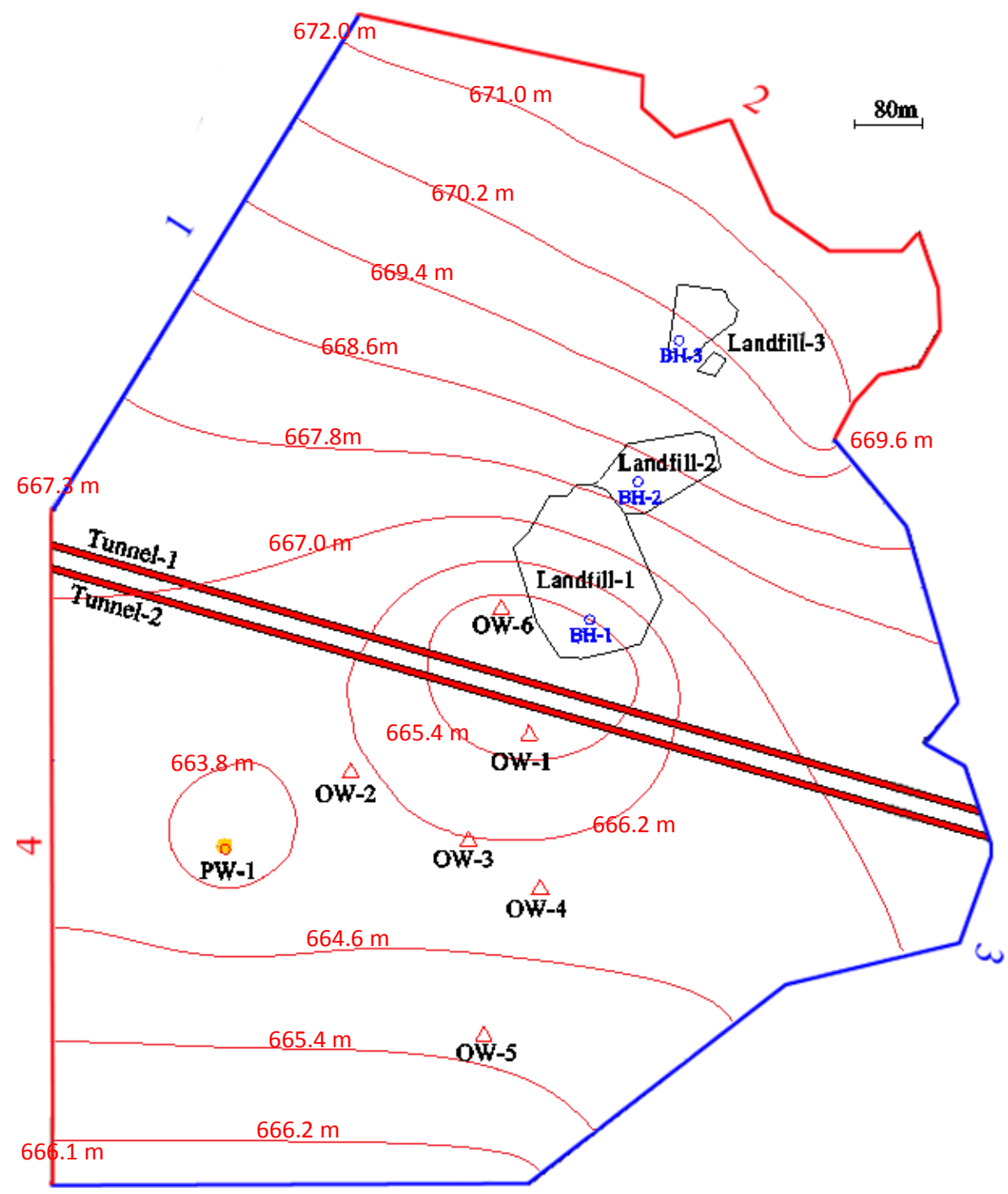

Figure 6. Original water level in January 2014. Red circle and red triangles stand for the pumping well (PW-1) and six monitoring wells $(O W-1,2,3,4,5$, and 6), respectively. $B H-3,2$, and 1 stand for the sampling points for Landfill-3, 2, and 1, respectively. Red boundary 4, 2 and the blue boundary 3, 1 stand for the fixed head boundary and zero-flow boundary, respectively

\section{Conceptualization of model}

There was a very thin aquitard composed of silt in the stratum of the study area. The tunnel in the study area could be assumed to be inlaid in the thin aquitard, therefore the area of the location of the tunnels and the silt aquitard were conceptualized into the second layer. In addition, the layers from the bottom to the top were set to confined, convertible and unconfined, respectively. The layer 3 and layer 1 are composed of sandstone and argillaceous sandstone, respectively. The MODFLOW and MT3D model 
for the studied area covered nearly $1.24 \mathrm{~km}^{2}$ and consisted of 199 columns and 199 rows. The thickness of the first layer ranged from $24.5 \mathrm{~m}$ in the northeast to $10.8 \mathrm{~m}$ in the south. The thickness of the second layer was $0.1 \mathrm{~m}$, beside that the tunnel area was $4.3 \mathrm{~m}$ to $4.6 \mathrm{~m}$. The thickness of the third layer was $19 \mathrm{~m}$. The drainage after tunnel excavation was generalized to the pumping well that was limited to the layer 2 . The displacement of the four drainage points was $1700-2000 \mathrm{~m}^{3} / \mathrm{d}$. A spatial view of the MODFLOW and MT3D model is shown in Figure 7.

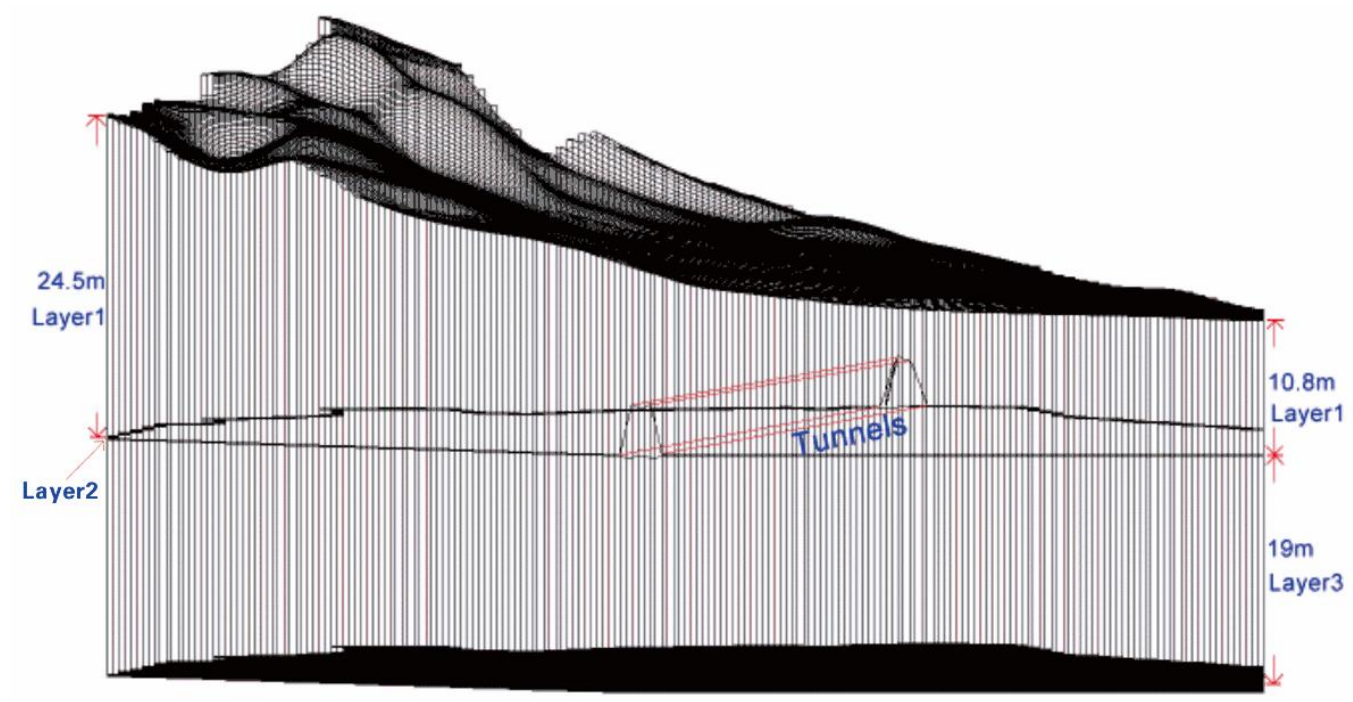

Figure 7. Spatial view of the MODFLOW and MT3D model

\section{Parameter configuration}

\section{Groundwater recharge}

The recharge values in the MODFLOW model were configured based on the monthly mean rainfall in Chengdu from 1970 to 2010. The recharge values and the amount of precipitation were represented by Equation 3 (Huan et al., 2015).

$$
Q_{r}=\lambda S_{r}
$$

where the coefficient of recharge $(\lambda)$ was consistently set to 0.19 from the precipitation (Feng et al., 2019); $Q_{r}$ is the groundwater recharge (m/d) and $S_{r}$ is the amount of precipitation. The recharge values and the average monthly precipitation are shown in Table 3.

Table 3. Average monthly precipitation from 1970 to 2010 and recharge values. (Source: http://www.weather.com.cn/cityintro/101270101.shtml)

\begin{tabular}{c|c|c|c|c|c|c|c|c|c|c|c|c}
\hline Month & $\mathbf{1}$ & $\mathbf{2}$ & $\mathbf{3}$ & $\mathbf{4}$ & $\mathbf{5}$ & $\mathbf{6}$ & $\mathbf{7}$ & $\mathbf{8}$ & $\mathbf{9}$ & $\mathbf{1 0}$ & $\mathbf{1 1}$ & $\mathbf{1 2}$ \\
\hline $\begin{array}{c}\text { Precipitation } \\
(\mathrm{mm})\end{array}$ & 7.8 & 12.2 & 20.2 & 44.4 & 78.7 & 106.8 & 224.5 & 201.3 & 118.8 & 35.4 & 15.9 & 5.2 \\
$\begin{array}{c}\text { Recharge values } \\
(0.00001 \mathrm{~m} / \mathrm{d})\end{array}$ & 5.0 & 8.0 & 13.0 & 28.0 & 50.0 & 67.0 & 142.0 & 127.0 & 75.0 & 22.0 & 10.0 & 3.0 \\
\hline
\end{tabular}




\section{Hydrological parameters}

The penetration coefficients in the first layer of the groundwater flow model were configured to vary in the range of $1.2 \sim 18.1 \mathrm{~m} / \mathrm{d}$. During model calibration for this layer, the range of parameter adjustment was directly set to $1.2 \sim 18.1 \mathrm{~m} / \mathrm{d}$. After correction, the horizontal penetration coefficient was $1.3 \mathrm{~m} / \mathrm{d}$. Following the general practice in the processing of penetration coefficients in hydrogeology, the vertical penetration coefficient was generally taken as one tenth of the horizontal penetration coefficient. Therefore, the vertical penetration coefficient was set to $0.13 \mathrm{~m} / \mathrm{d}$. After tunnel excavation began, the specific storage and specific yield of the first layer in the groundwater flow model were set to $0.00002 \mathrm{~m}^{-1}$ and 0.21 , respectively. The configuration of the penetration coefficients in the second layer was more complex. The settings are displayed in Figure 8, where blue color represents the regions between the two tunnels, red color represents the tunnel under excavation, and white shows the ordinary region.

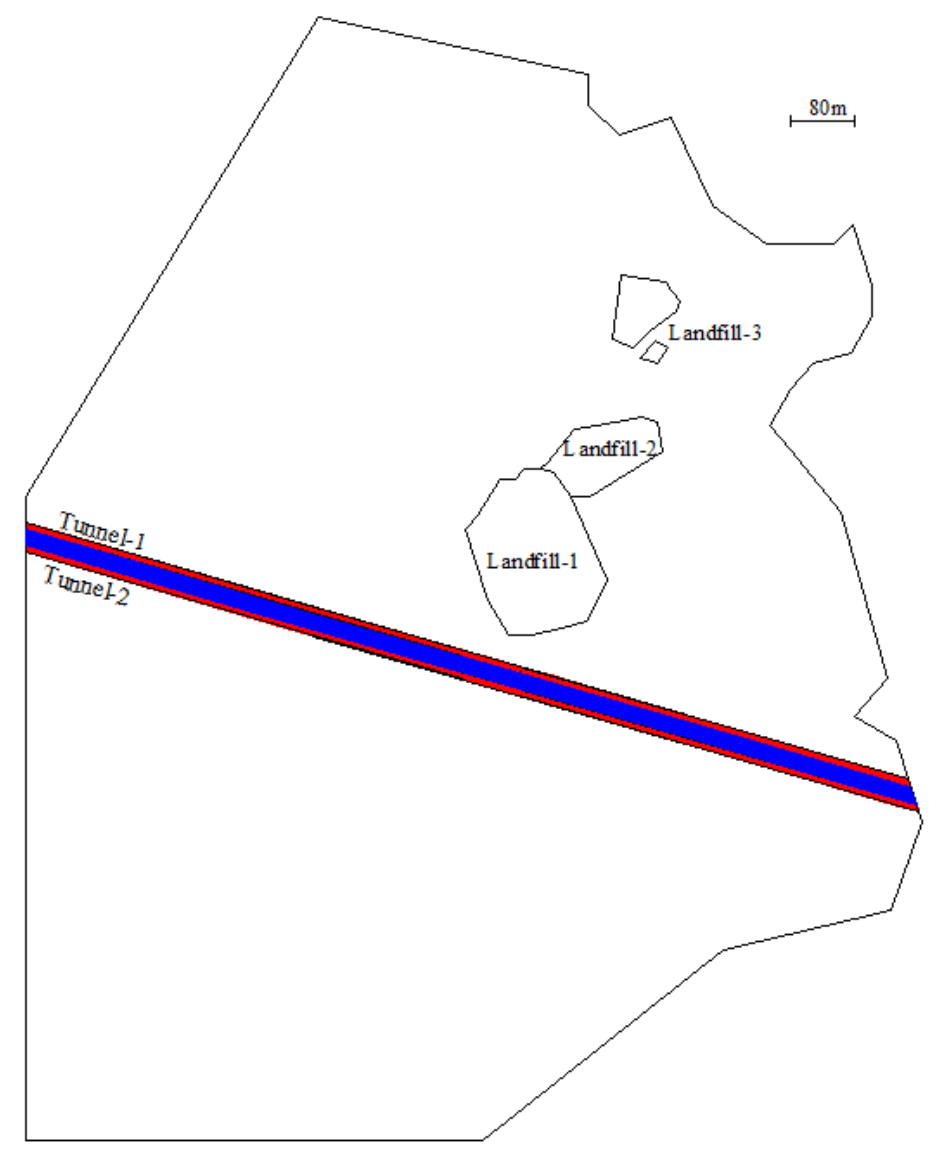

Figure 8. Distribution of hydraulic conductivity coefficients of the second layer of model after tunnel excavation began

The white region was silt, where the horizontal and vertical hydraulic conductivity coefficients were $0.005 \mathrm{~m} / \mathrm{d}$ and $0.0005 \mathrm{~m} / \mathrm{d}$, respectively. Blue region was the argillaceous sandstone soaked in the leachate. For this region, the hydraulic conductivity coefficient was multiplied by the weighting factor of 1.21 that was obtained from the test. The horizontal and vertical hydraulic conductivity coefficients 
were set to $1.5 \mathrm{~m} / \mathrm{d}$ and $0.16 \mathrm{~m} / \mathrm{d}$, respectively. The specific storage and specific yield of the second layer in the groundwater flow model were set to $0.00002 \mathrm{~m}^{-1}$ and 0.08 , respectively. The specific storage and specific yield of the third layer in the groundwater flow model were set to $3.6 \mathrm{~m} / \mathrm{d}$ and $0.36 \mathrm{~m} / \mathrm{d}$, respectively. For the geological medium in this layer, the specific yield and specific storage were set to 0.21 and $0.00002 \mathrm{~m}^{-1}$, respectively. Table 4 shows the hydraulic conductivity coefficients, specific yield, specific storage and formation thickness of each layer in the groundwater flow model after the beginning of the tunnel excavation. According to the results of the field test, the original concentrations of sulfate ions at Landfill-1, Landfill-2 and Landfill-3 were all set to $5000 \mathrm{mg} / \mathrm{L}$; the original concentrations of other grids were set to 0 . The longitudinal dispersivity $(\mathrm{m})$, transverse dispersivity $(\mathrm{m})$, and vertical dispersivity $(\mathrm{m})$ were set to $10 \mathrm{~m}, 1 \mathrm{~m}$ and $0.1 \mathrm{~m}$, respectively. All the values were assigned using the earlier study done by Feng et al. (2019)

Table 4. Hydraulic parameters of the three layers

\begin{tabular}{c|c|c|c|c|c|c}
\hline $\begin{array}{c}\text { Layer } \\
\text { number }\end{array}$ & Aquifer type & $\begin{array}{c}\text { Specific } \\
\text { yield }\end{array}$ & $\begin{array}{c}\text { Specific } \\
\text { storage }\left(\mathbf{m}^{-\mathbf{1}}\right)\end{array}$ & $\mathbf{K}_{\mathbf{x}}, \mathbf{K}_{\mathbf{y}}(\mathbf{m} / \mathbf{d})$ & $\mathbf{K}_{\mathbf{z}}(\mathbf{m} / \mathbf{d})$ & Thickness (m) \\
\hline 1 & Unconfined & 0.21 & 0.00002 & 1.30 & 0.13 & $10.8-24.5$ \\
\hline 2 & Convertible & 0.08 & 0.00002 & $\begin{array}{c}\text { Blue: } 1.50 \\
\text { White: } 0.005 \\
\text { Red: } 0.000009\end{array}$ & $\begin{array}{c}\text { Blue: } 0.16 \\
\text { White: } 0.0005\end{array}$ & 0.10 \\
& Red: 0.000009 & \\
\hline 3 & Confined & 0.21 & 0.00002 & 3.60 & 0.36 & 19.00 \\
\hline
\end{tabular}

\section{Calibration and validation of groundwater flow model}

After the beginning of the tunnel excavation, the measured groundwater levels of observation wells in the study area in 2014 and 2015 were collected. The year of calibration and validation was 2014 and 2015, respectively. For calibration of the simulated and measured groundwater level, the hydraulic conductivity coefficients were varied. The simulated groundwater level was calibrated against the measured water levels of six observation wells from January 2014 to December 2015, until the simulation agreed well with the observation (Panagopoulos, 2012). Changes in the measured groundwater levels in the observation wells OW-1, OW-2, OW-3, OW-4, OW-5 and OW-6 and simulated values from the groundwater flow model during calibration (2014) and validation (2015) after the excavation began are shown in Figure 9. At the end of the calibration period of the groundwater flow model (December 2014), the maximum difference between simulated and measured groundwater level simultaneously occurred at $\mathrm{OW}-1, \mathrm{OW}-2$ and $\mathrm{OW}-3$, the difference being $0.15 \mathrm{~m}$; difference was $0.06 \mathrm{~m}$ at OW-4, $0.03 \mathrm{~m}$ at OW-5 and $0.01 \mathrm{~m}$ at OW-6. None of the difference at the end of the calibration period exceeded $0.2 \mathrm{~m}$. At the end of the validation period of the groundwater flow model after the excavation began (December 2015), the maximum difference between the simulated and the measured groundwater level occurred at OW-1 was $0.14 \mathrm{~m}$; the difference was $0.05 \mathrm{~m}$ at $\mathrm{OW}-2,0.03 \mathrm{~m}$ at $\mathrm{OW}$ $3,0.02 \mathrm{~m}$ at $\mathrm{OW}-4,0.03 \mathrm{~m}$ at $\mathrm{OW}-5$ and $0.02 \mathrm{~m}$ at OW-6. None of the difference at the end of the calibration period exceeded $0.15 \mathrm{~m}$. On the whole, the difference at the end of the validation period of the model (December 2015) was smaller than that at the end of the calibration period of the model (December 2014), indicating that the parameter adjustment achieved a certain effect. 

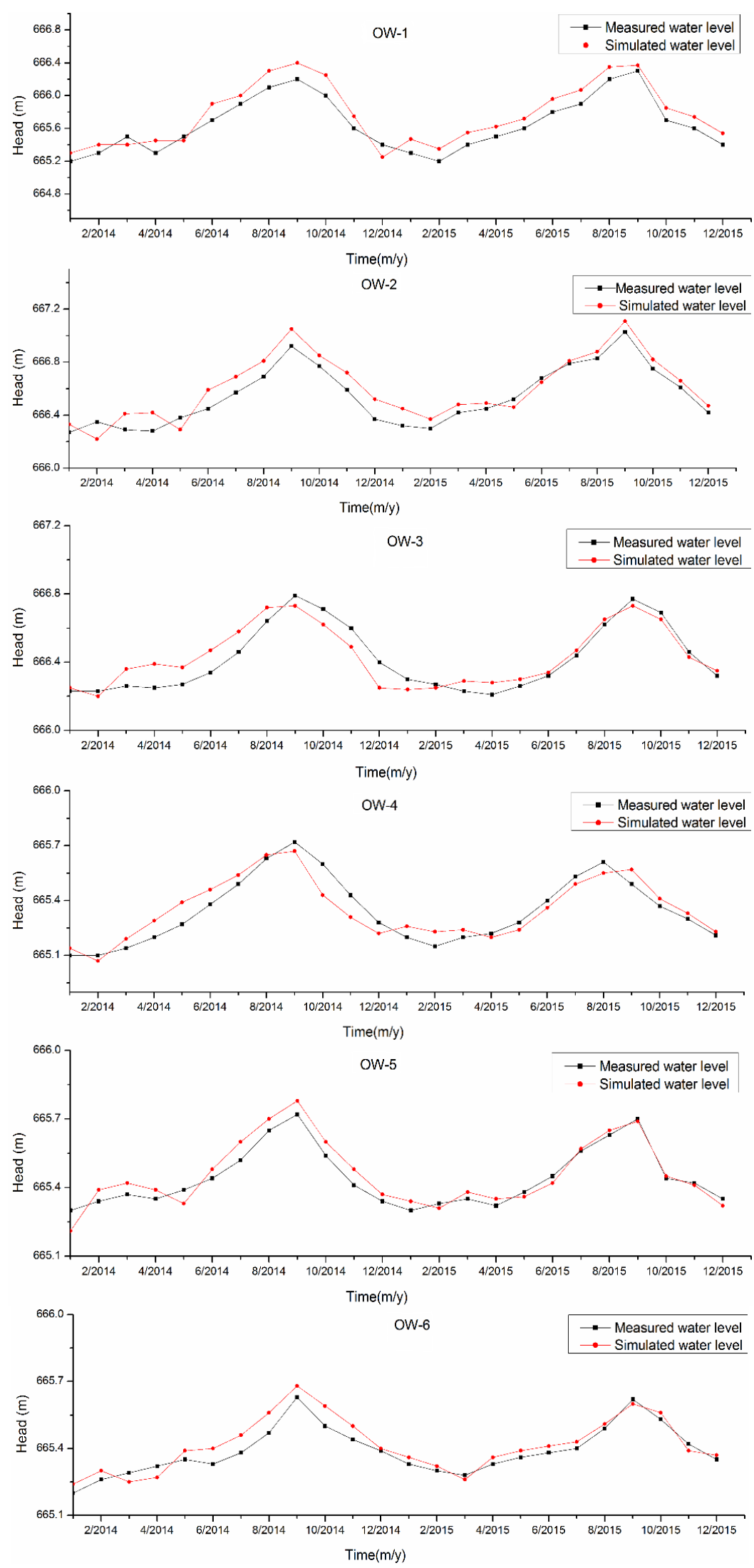

Figure 9. Head changes in the simulation and measured water level of the $O W-1,2,3,4,5,6$ observation well in the groundwater flow model after tunnel excavation in the calibration process (2014) and the verification process (2015) 


\section{Simulation results}

\section{Groundwater flow simulation results}

The simulated groundwater level in the first stress period after the validation of the groundwater flow model under tunnel excavation is shown in Figure 10, and the time was January 2016.

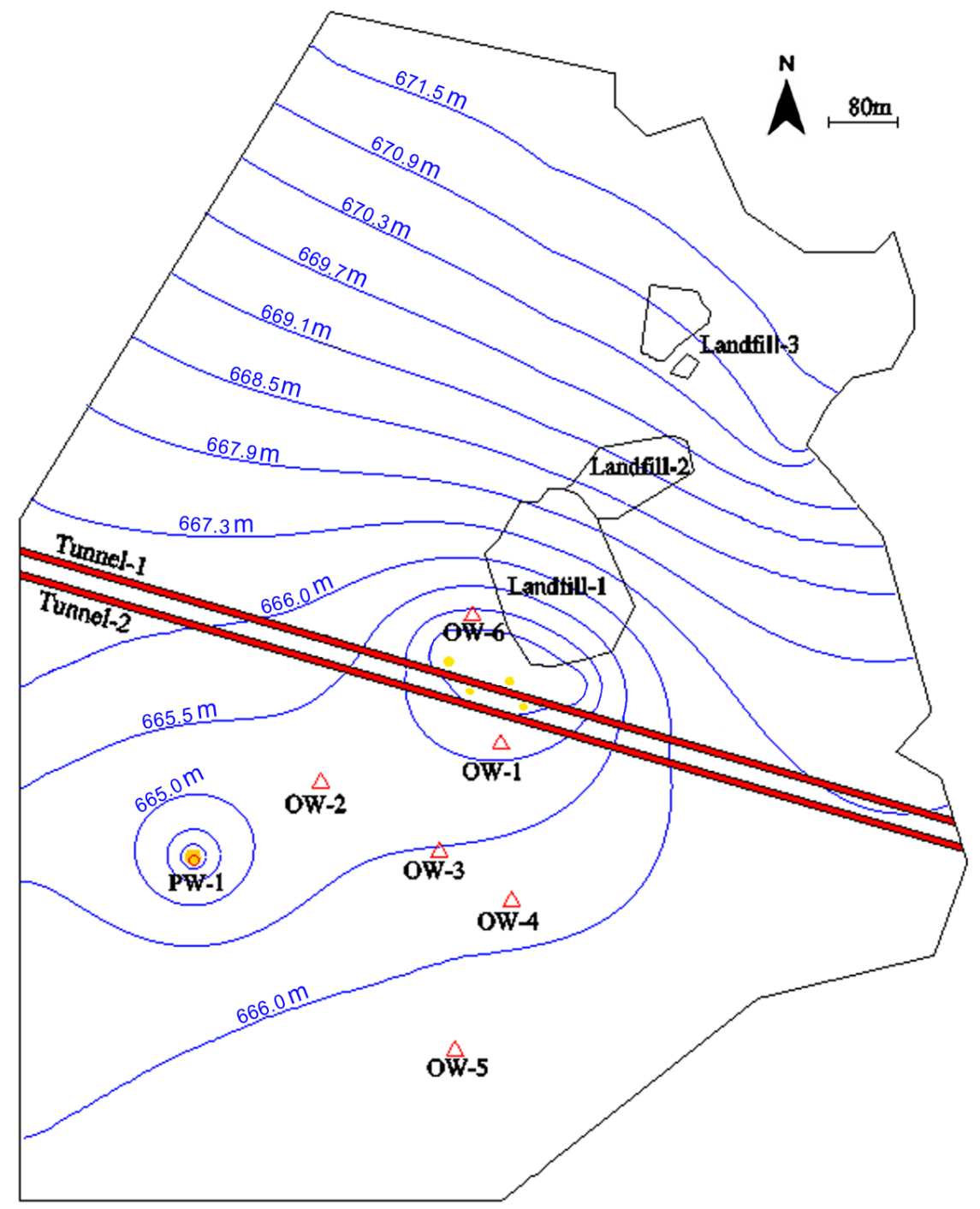

Figure 10. Simulated groundwater level from the groundwater flow model in January 2016 after tunnel excavation began

A precipitation funnel was formed near the middle section of the tunnel and PW-1. After the beginning of the tunnel excavation, four drainage sites were represented by small yellow circles. The amount of tunnel drainage varied within the range of $1700 \sim 2000 \mathrm{~m}^{3} / \mathrm{d}$. Tunnel drainage was conceptualized as a pumping well in a confined formation, which was the second layer. All the groundwater levels at the north and south sides of the tunnel in Figure 10 were higher than the original groundwater level in Figure 6, and the water lines were denser. This indicated that the tunnel impeded the groundwater flow. Moreover, there was a large fluctuation in the simulated groundwater 
level after the beginning of the tunnel excavation, which was attributed to the tunnel drainage. It was also found that the groundwater level showed greater fluctuations due to tunnel drainage than due to the pumping wells. Barrier to the groundwater flow and drainage due to the presence of tunnel decreased the pumping rate of $\mathrm{PW}-1$.

\section{Results of solute transport simulation}

In the simulation of the solution transport under the tunnel excavation, it was necessary to import the results of groundwater flow simulation under excavation in advance. The solute transport model conceptualized three formations. However, while presenting the results of the transport of the pollutants, only the pollution plumes of the aquifer (first layer) and the convertible formation (second layer) are shown. Figures 11 and 12 show the pollution plumes of the sulfate ions in the first layer (aquifer) of the solute transport model in December 2020 and December 2030, respectively.

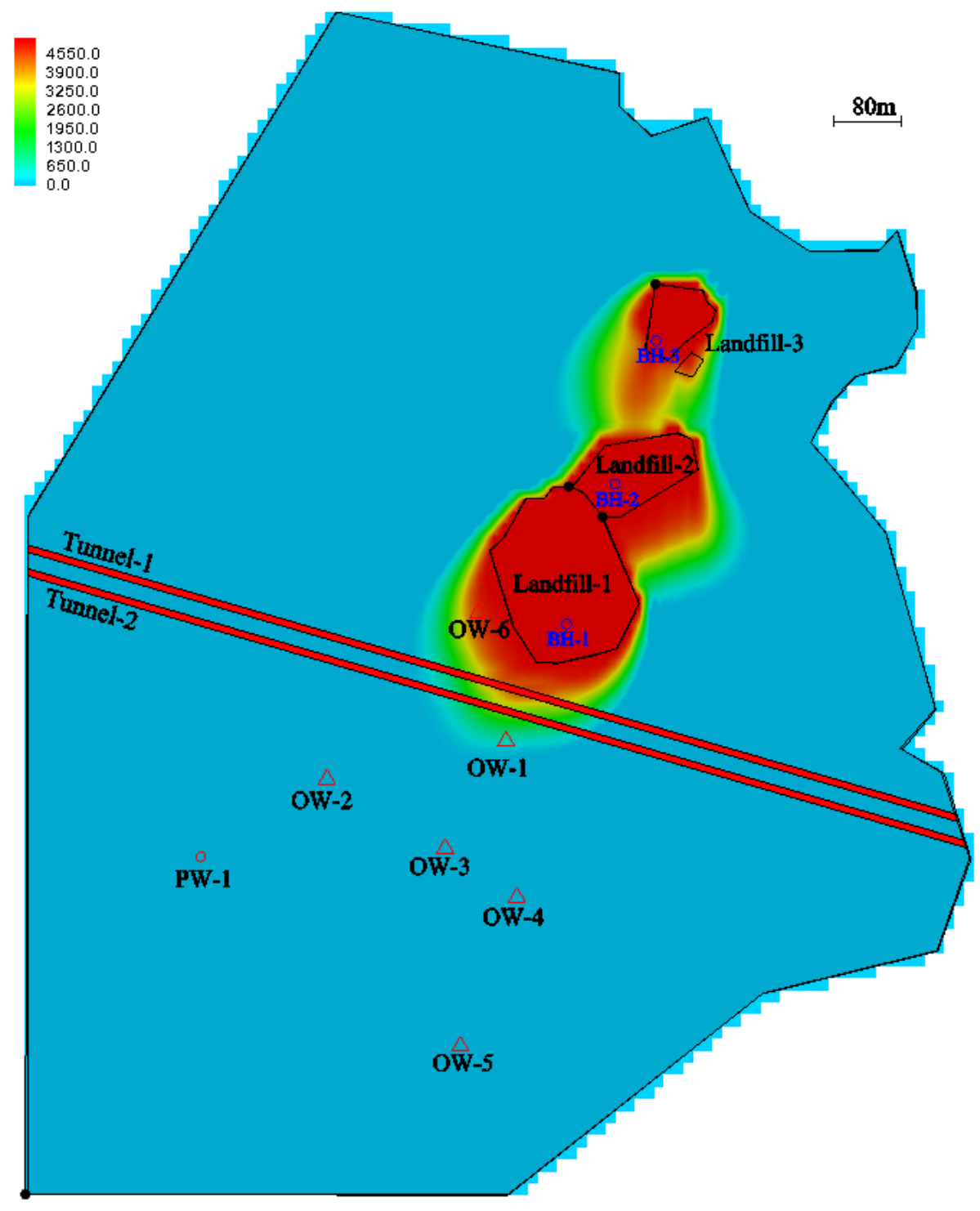

Figure 11. Pollution plumes of sulfate ions in the aquifer (first layer) of the solute transport model under excavation in December 2020 


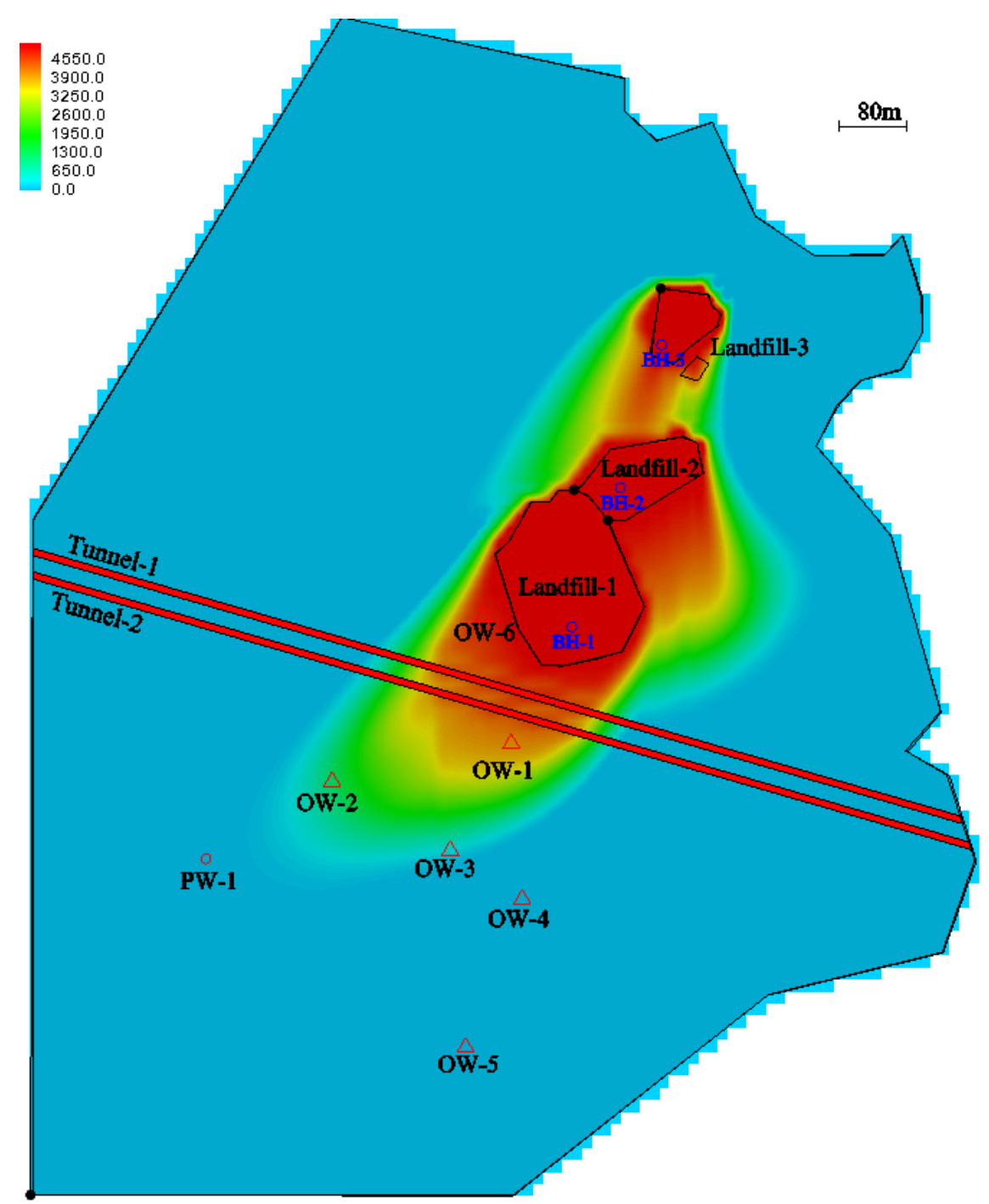

Figure 12. Pollution plumes of sulfate ions in the aquifer (first layer) of the solute transport model under excavation in December 2030

For the first layer, the pollution plumes just reached the OW-1 in December 2020. The concentrations of sulfate ions at OW-1 and OW-6 were $559 \mathrm{mg} / \mathrm{L}$ and $4115 \mathrm{mg} / \mathrm{L}$, respectively. In December 2030, the plumes in the first layer completely covered OW-1, OW-2 and OW-6 and the transverse plumes just arrived at OW-3, while the vertical plumes had not yet arrived at PW-1. Observations at OW-1, OW-2, OW-3 and OW-6 indicated that the concentrations of sulfate ions were $3338 \mathrm{mg} / \mathrm{L}, 1872 \mathrm{mg} / \mathrm{L}, 440 \mathrm{mg} / \mathrm{L}$ and $4542 \mathrm{mg} / \mathrm{L}$, respectively. Table 5 shows the observed concentrations of the sulfate ions in the observation/pumping wells in the aquifer (first layer) of the solute transport model under tunnel excavation in December 2020 and December 2030, respectively.

Figures 13 and 14 show the pollution plumes of the sulfate ions in the second layer (convertible formation) of the solute transport model in December 2020 and December 2030 , respectively. In practice, the shape of pollution plumes depends on several factors, including the groundwater flow rate, pressure head, distribution of hydraulic conductivity coefficients, and shape of the pollution source. A continuous leakage of landfill leachate represented a stable pollution source in the model. However, the 
distribution features of the sulfate ions in the convertible formation were very different from those of the ordinary pollutants, and the reason was the irregular penetration path formed between the two tunnels. The hydraulic conductivity coefficients between the two tunnels increased due to the soaking of the surrounding rocks in the landfill leachate. As a result, the downward penetration of the sulfate ions from the first layer via the regions between the two tunnels was enhanced. In other words, the migration path of some the sulfate ions was indeed altered by the tunnel excavation. Table 6 shows the observed concentrations of sulfate ions at the observation/pumping wells in the convertible formation (second layer) of the solute transport model under tunnel excavation in December 2020 and December 2030.

Table 5. Comparison of sulfate ion concentrations in the aquifer (first layer) of the solute transport model under excavation between December 2020 and December 2030

\begin{tabular}{c|c|c|c|c|c|c|c|c}
\hline & \multirow{2}{*}{$\begin{array}{c}\text { Time of } \\
\text { simulation }\end{array}$} & \multicolumn{4}{|c}{$\begin{array}{c}\text { Sulfate ion concentrations at the } \\
\text { observation/pumping wells (mg/L) }\end{array}$} \\
\cline { 3 - 9 } & & PW-1 & OW-1 & OW-2 & OW-3 & OW-4 & OW-5 & OW-6 \\
\hline Solute transport model (first & December 2020 & 0** & $559 * *$ & $0 * *$ & $0 * *$ & $0 * *$ & $0 * *$ & $4115 * *$ \\
layer) under tunnel excavation & December 2030 & $0 * *$ & $3338 * *$ & $1872 * *$ & $440 * *$ & $0 * *$ & $0 * *$ & $4542 * *$ \\
\hline
\end{tabular}

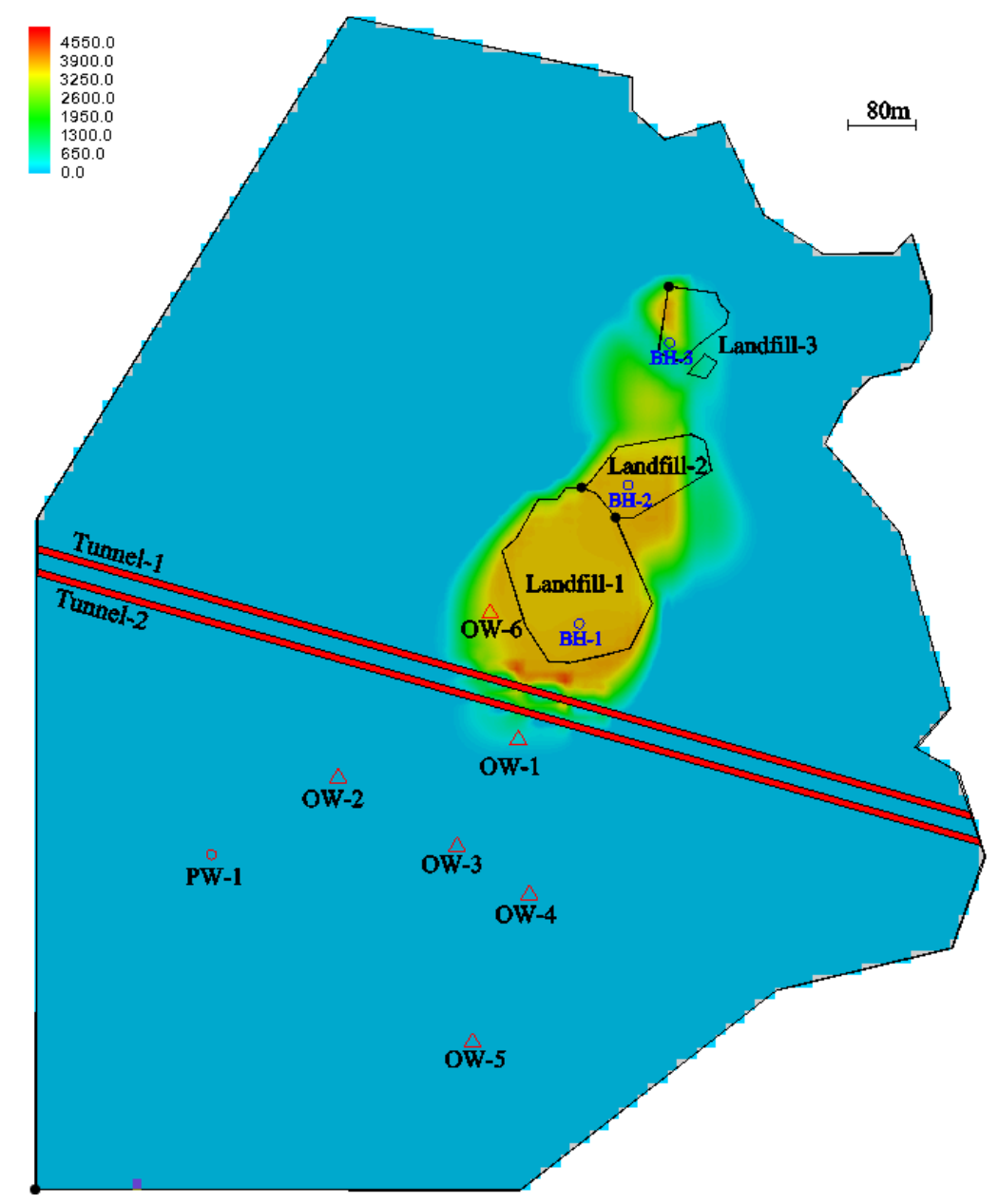

Figure 13. Convertible formation (second layer) of the solute transport model under excavation. Pollution plumes of sulfate ions in December 2020 


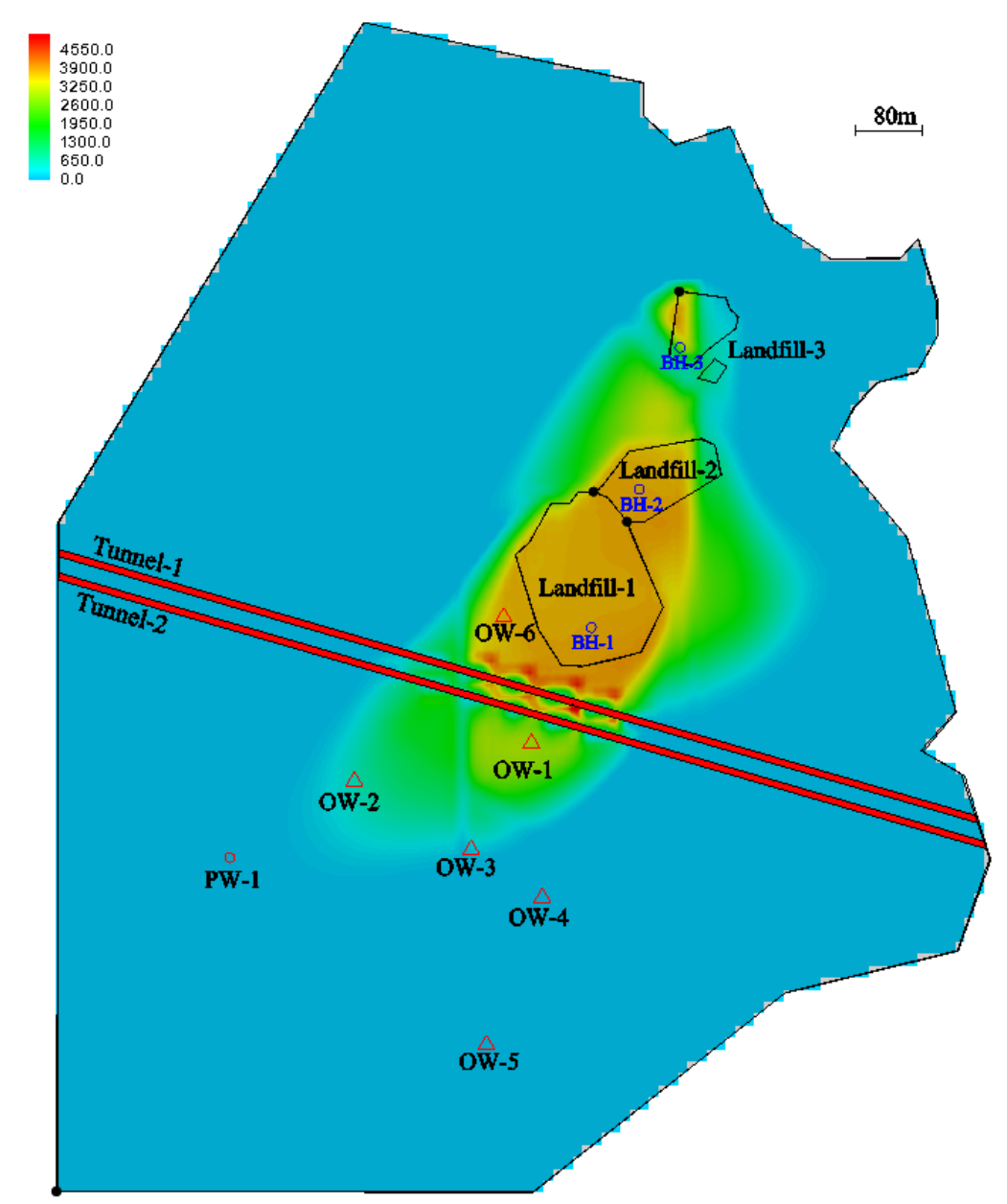

Figure 14. Convertible formation (second layer) of the solute transport model under excavation. Pollution plumes of sulfate ions in December 2030

Table 6. Comparison of sulfate ion concentrations in the convertible formation (second layer) of the solute transport model under excavation between December 2020 and December 2030

\begin{tabular}{l|c|c|c|c|c|c|c|c|c}
\hline & \multirow{2}{*}{$\begin{array}{c}\text { Time of } \\
\text { simulation }\end{array}$} & \multicolumn{5}{|c}{$\begin{array}{c}\text { Sulfate ion concentrations at the } \\
\text { observation/pumping wells (mg/L) }\end{array}$} \\
\cline { 5 - 9 } & & PW-1 & OW-1 & OW-2 & OW-3 & OW-4 & OW-5 & OW-6 \\
\hline Solute transport model (second & December 2020 & 0** & $559 * *$ & $0 * *$ & $0 * *$ & $0 * *$ & $0 * *$ & $3146 * *$ \\
layer) under tunnel excavation & December 2030 & 0** & $2788 * *$ & $578 * *$ & $257 * *$ & $0 * *$ & $0 * *$ & $3544 * *$ \\
\hline
\end{tabular}

\section{Discussion and conclusion}

(1) By comparing the test results, it was found that the confining pressure exhibited a greater impact on the overall trend of the permeability curve. This was also indicated by the shape of the permeability curve, since, the rate of variation at the increasing permeability stage decreased with the increase in the confining pressure. The maximum permeability of rock specimens occurred after the peak strength, that is, after the fracture of specimens. When a macroscopic fracture plane was formed inside the 
specimen, this plane would become the preferential seepage channel, leading to a sudden increase in permeability. The mean values of the differences in the permeability between rock specimens with or without soaking were taken into consideration, after the beginning of the tunnel excavation under the same confining pressure and penetration pressure. On an average, it was found that the permeability of the specimens soaked in leachate was increased by $21 \%$.

(2) Tunnel drainage in the model was conceptualized as a pumping well confined in the second layer. According to groundwater level simulation in January 2016, a precipitation funnel was formed near the middle segment of the tunnel and PW- 1 . Tunnel drainage in the model was conceptualized as a pumping well confined in the second layer. All the simulated groundwater levels in the north and south sides of the tunnel were higher than the original groundwater level, and the water lines were also denser. This indicated the barrier to the flow of the groundwater due to the presence of the tunnel. Moreover, there was large fluctuation in the simulated groundwater level after the beginning of the tunnel excavation, which was attributed to the tunnel drainage. It was also found that the groundwater level fluctuated more prominently due to the tunnel drainage, than due to the pumping wells. Furthermore, the presence of tunnel acts as a barrier to the groundwater flow and the drainage, thereby decreasing the pumping rate of PW-1.

(3) The distribution of the sulfate ion concentration in the second layer of model between the two tunnels showed an irregular pattern. The hydraulic conductivity coefficients between the two tunnels increased due to the soaking of surrounding rocks in the landfill leachate. As a result, the downward penetration of sulfate ions from the first layer via the regions between the two tunnels was enhanced. As the tunnel excavation accelerated the downward penetration of pollutants, this would lead to the pollution of deep groundwater. Therefore, the tunnel excavation area should not only pay attention to surface pollution, but also pay attention to underground pollution. In addition, it was necessary for the study area to conduct drilling sampling studies to support concentration simulation results.

\section{REFERENCES}

[1] Ando, K., Kostner, A., Neuman, S. P. (2003): Stochastic continuum modeling of flow and transport in a crystalline rock mass: Fanay-Augeres, France, revisited. - Hydrogeology Journal 11(5): 521-535.

[2] Brace, W. F., Walsh, J. B., Frangos, W. T. (1968): Permeability of granite under high pressure. - Journal of Geophysical Research 6(73): 2225-2236.

[3] Du, Y. J., Shen, S. L., Liu, S. Y., Hayashi, S. (2009): Contaminant mitigating performance of Chinese standard municipal solid waste landfill liner system. Geotextiles and Geomembranes 27(3): 232-239.

[4] Ersoy, H., Bulut, F., Berkun, M. (2013): Landfill site requirements on the rock environment: A case study. - Engineering Geology 154(28): 20-35.

[5] Feng, Y. S., Jin, X. G. (2019): Studies on effects of traffic tunnels on the migration of the contaminants under landfill sites. - Environmental Science and Pollution Research 21(2): $1-17$.

[6] Han, D. M., Tong, X. X., Currell, M. J., Gao, G. L., Jin, M. G., Tong, C. S. (2014): Evaluation of the impact of an uncontrolled landfill on surrounding groundwater quality, Zhoukou, China. - Journal of Geochemical Exploration 136: 24-39. 
[7] Han, Z. Y., Ma, H. N., Shi, G. Z., He, L., Wei, L. Y., Shi, Q. Q. (2016): A review of groundwater contamination near municipal solid waste landfill sites in China. - Science of the Total Environment 569-570(1): 1255-1264.

[8] Huan, H., Wang, J. S., Lai, D. S., Teng, Y. G., Zhai, Y. Z. (2015): Assessment of well vulnerability for groundwater source protection based on a solute transport model: a case study from Jilin City, northeast China. - Hydrogeology Journal 23(3): 581-596.

[9] Jamrah, S., Al-Futaisi, A., Rajmohan, N., Al-Yaroubi, S. (2008): Assessment of groundwater vulnerability in the coastal region of Oman using DRASTIC index method in GIS environment. - Environmental Monitoring and Assessment 147(1): 125-138.

[10] Jiang, X. W., Wan, L., Yeh, T. C. J., Wang, X. S., Xu, L. (2010): Steady-state discharge into tunnels in formations with random variability and depth-decaying trend of hydraulic conductivity. - Journal of Hydrology 387(3-4): 320-327.

[11] Lin, H. L., Lee, C. H. (2009): An approach to assessing the hydraulic conductivity disturbance in fractured rocks around the Syueshan tunnel, Taiwan. - Tunnelling and Underground Space Technology 24(2): 222-230.

[12] Liu, C. W., Lin, C. N., Jiang, C. S., Ling, M. W., Tsai, J. W. (2011): Assessing nitrate contamination and its potential health risk to Kinmen residents. - Environmental Geochemistry and Health 33(5): 503-514.

[13] McDonald, M. G., Harbaugh, A. W. (1988): A modular three dimensional finite difference ground-water flow model. - Report in series Techniques of Water-Resources Investigations of US Geological Survey. Vol. 6. DOI: 10.3133/twri06A1.

[14] Molinero, J., Samper, J. (2006): Large-scale modeling of reactive solute transport in fracture zones of granitic bedrocks. - Journal of Contaminant Hydrology 82(3-4): 293318.

[15] Panagopoulos, G. (2012): Application of MODFLOW for simulating groundwater flow in the Trifilia karst aquifer, Greece. - Environmental Earth Sciences 67(7): 1877-1889.

[16] Pastoules, M. G., Gripps, J. C. (1982): An investigation of the permeability of Yorkshire Chalk under differing pore water and confining pressure conditions. - Energy Sources 6(4): 321-334.

[17] Zhan, T. L. T., Guan, C., Xie, H. J., Chen, Y. M. (2014): Vertical migration of leachate pollutants in clayey soils beneath an uncontrolled landfill at Huainan, China: a field and theoretical investigation. - Science of the Total Environment 470: 290-298.

[18] Zheng, C., Wang, P. P. (1999): MT3DMS: A Modular Three Dimensional Multispecies Transport Model for Simulation of Advection, Dispersion, and Chemical Reactions of Contaminants in Groundwater Systems. Documentation and User's Guide. - US Army Corps of Engineers, Vicksburg, MS.

[19] Zhou, Y., Jiang, Y. H., An, D., Ma, Z. F., Xi, B. D., Yang, Y., Li, M. X., Hao, F. H., Lian, X. Y. (1999): Simulation on forecast and control for groundwater contamination of hazardous waste landfill. - Environmental Earth Sciences 72(10): 4097-4104.

[20] Zimmerman, R. W. (2000): Coupling in poroelasticity and thermoelasticity. International Journal of Rock Mechanics \& Mining Sciences 1(31): 79-81. 